\title{
The in vitro assessment of anti proliferation activity of crude diethyl ether extract of Dendrophthoe species against to myeloma culture cell
}

\author{
Mochamad Lazuardi \\ Veterinary Faculty Airlangga University \\ Surabaya - Indonesia
}

\begin{abstract}
Herb medicine have an active substances that can dissolved on polar, semi polar and non polar liquid extract. The methanol and ethyl acetate as a polar and semi polar extract liquid were used to study of herb medicine such as Dendrophthoe species. Diethyl ether as a non polar liquid extract was never use to study the Dendrophthoe species. The aim of this study was to investigate the anti proliferation activity of Dendrophthoe species to myeloma culture cells after extracted by non-polar extract solution (diethyl ether). The post test only control group design was used for this research. A thirty six of microtiterplates wells were used for myeloma culture cells in RPMI medium. The wells were devided placing in two groups: treatment groups and controls groups. Each three wells of six treatment subgroups added with $100 \mu \mathrm{l}$ of 1.1; 5.5; 11; 22; 33 and $44 \mu \mathrm{g} / \mathrm{ml}$ crude diethyl ether extract series. A RPMI solution at similar method and volume were used as control substances. The cells were assessed by inverted microscope in 200x magnified two days after. The cells were quantified analyzed for anti proliferation activity by using 1:1 methylene blue solution. The results showed that started from $11.0 \mu \mathrm{g} / \mathrm{ml}$ of crude diethyl ether extract of Dendrophthoe species have been anti proliferation abilities of myeloma culture cells $(p<0.05)$. In conclusion, actives substances of Dendrophthoe species where dissolved in non polar liquid as diethyl ether has anti proliferation activities to cancer cell in vitro.
\end{abstract}

Key words: cancer, herb medicine, myeloma, Dendrophthoe species, anti proliferation

Correspondence: Mochamad Lazuardi, c/o: Veterinary Faculty, Airlangga University. Jln. Mulyorejo (Kampus C) Universitas Airlangga Surabaya 60115, Indonesia. E-mail: ardiunair@yahoo.co.uk

\section{INTRODUCTION}

The cases of oral squamous cell carcinoma (OSCC) were known highly in the worldwide at about $80 \%$ to $90 \%$ of malignant tumor in oral cavity. The mortality rate remains high about $5 \%$ in worldwide and $2.4 \%$ to $3.57 \%$ in Indonesia. ${ }^{1}$

Some of chemotherapeutics for reduced development of proliferates cell as carcinoma like an OSCC were seen expensive and not a lot of kinds. A practical solution to this problems as described at above is using traditional plant remedies for reduce highly cost of medication.

Dendrophthoe species (Benalu duku) is a traditional Indonesian herbal remedy which grows to a height of $20 \mathrm{~cm}$ to $30 \mathrm{~cm}$ (Figure 1). That trees have a some specific traditional name as follows; Pasilan on Depok (Jakarta) and Dendrophthoe on Palembang (South of Sumatera). In vivo and in vitro experimentally, the hot water extract of leaves of Dendrophthoe species were shown have an anti proliferation of myeloma cells., ${ }^{2,3}$

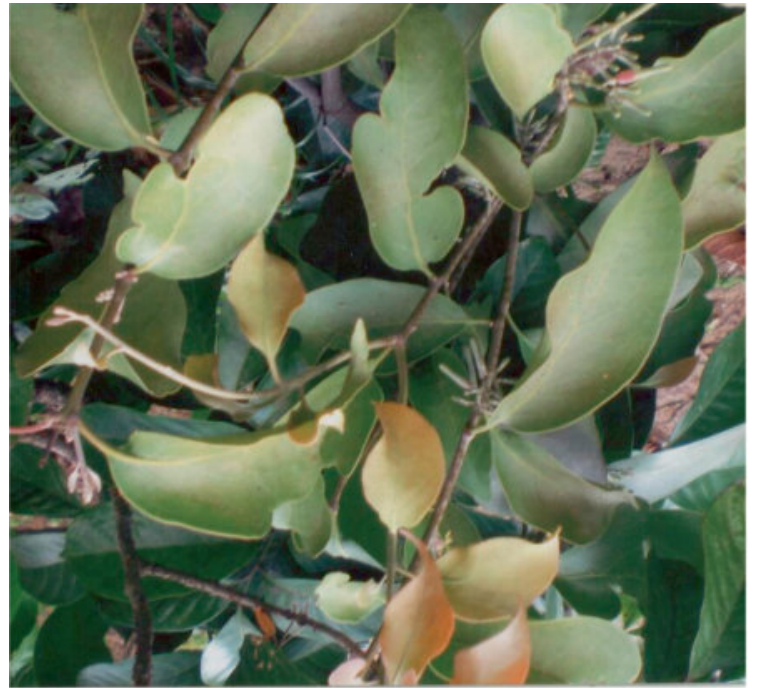

Figure 1. The leaves of Dendrophthoe species (Benalu duku) from Muara Enim (South of Sumatera island). 
The ethanol, methanol and chloroform extract of Dendrophthoe species were known too, have an anti proliferation ability for myeloma culture cell. ${ }^{4-6}$ The phenomenon at above showed that leaves of Dendrophthoe species have a something substances dissolved in polar solution with anti proliferation ability against to cancer culture cell or analogues as an anti cancer against to carcinoma cells. Nuraini et al., ${ }^{7}$ reported that ethyl acetate extract of leaves of Dendrophthoe species as a semi polar solvent had a anti proliferation activities to development of myeloma culture cells. But we did not known yet, potency of anti proliferation substances of leaves of Dendrophthoe species where dissolved in non-polar solvent. Diethyl ether, one of non-polar solvent was known commonly use for extract solvent of unknown herbal medicinal. ${ }^{8}$ By these problems as described at above, we will be exploring potency of diethyl ether extract of leaves of Dendrophthoe species as anti proliferation cancer culture cell to obtain concentration data where have a minimum anti proliferation ability against to in vitro cancer culture cell.

\section{MATERIAL AND METHODS}

Research design of this work were using experimentally, by post test only control group design with inhibition ability activities as dependent variable and crude extract of Dendrophthoe species and myeloma cells as dependent variable.

The air-dried stem barks of Dendrophthoe species leaves were collected from Muara Enim, South of Sumatera, Indonesia. A voucher specimen of Dendrophthoe species has been identified and deposit in Peer Groups Researcher of Herb Medicines of Department Medical-Pharmacy, Medical Faculty Airlangga University.

The leaves of Dendrophthoe species were pulverization and weighing carefully at about $850 \mathrm{~g}$ for dissolved in 2.5 $\mathrm{L}$ of diethyl ether p.a during the days. The mixture were processed by macerate method and filtrating with Buchner filter for obtained filtrate of diethyl ether. The residues were processing on similar method at 3 times iterates. 7.5 L filtrates were pooled on one bottle and evaporating by for obtained at about 4-5 g dried filtrate as stock sample. The sample stocks were diluted with Rose Well Park Memorial Institute (RPMI) medium and performed on series samples as follows; a $100 \mathrm{mg}$ of dried stock samples dissolved up to $100 \mathrm{ml}$ of RPMI medium (100 ppm) and performed to $1.1 ; 5.5 ; 11 ; 22 ; 33.0$, and 44.0 ppm of RPMI. Small volume of sample series and medium of RPMI were tested by Thioglicolate and incubate during the two days $\left(37^{\circ} \mathrm{C}\right)$.

The myeloma cell lines (P3UI type) were obtained from the center of Veterinary Pharmaceutics, Directorate of Livestock Services, Agriculture Department, Surabaya (Indonesia). From storage of $-80^{\circ} \mathrm{C}$, the cells were thawing and revival to propagates in $100 \mathrm{ml}$ Roux's bottle at least $9 \times 10^{7}$ cells $/ \mathrm{ml}$ as stock cells. The stock cells were distributing to $2 \mathrm{ml}$ of 36 microtiterplates wells at least $2 \times 10^{4}$ cells $/ \mathrm{ml}$ each well.

A $100 \mu \mathrm{l}$ crude extract of Dendrophthoe species at ranging 1 to $40 \mu \mathrm{g} / \mathrm{ml}$ were inserting onto 18 wells of microtiterplates and it was consists of $2 \mathrm{ml}$ of RPMI medium with $10 \%$ of Fetal Bovine Serum (FBS) and myeloma culture cells. A similar procedure of $100 \mu \mathrm{l}$ RPMI solution as control substance were using for treat of myeloma in micro titer plates at control group wells. All samples were following propagates and inserting into $\mathrm{CO}_{2}$ incubator during the 48 hours. Two days later, the cells of all samples in microtiterplates were re-suspended. A $5 \mu \mathrm{l}$ of the samples were mixture with 1:1 of $10 \%$ methylene blue solution (w/v) and dropped on the top of haemocytometer Thoma. By inverted microscope at $200 \times$ magnified, the viable cell were counting referred to equation 1 for obtained total viable cell data as illustrated of anti proliferate ability of crude diethyl ether extract.

Total viable cells each well $=$

$$
\frac{\text { Amount of viable cell in } 5 \mu \mathrm{l}}{5 \mu \mathrm{l}} \times 2095 \mu \mathrm{l} \quad \text { Equation I }
$$

The criterion of anti proliferation ability of crude diethyl ether extract of Dendrophthoe species were described in table $1 .^{6}$

The data were comparing each other by MINITAB 13.3 (treatment group vs., control group) at series concentration of $1.1 \mathrm{ppm}$ to $44.0 \mathrm{ppm}$. The conclusions of these researches were performed from research analyzed of independent $\mathrm{T}$ test at $5 \%$ significance of treatment groups vs., control groups.

Table 1. The anti proliferation ability of crude diethyl ether extract of Dendrophthoe species

The 24 wells of microtiterplate on $2 \mathrm{ml}$ RPMI medium

\begin{tabular}{clc}
\hline Amount of viable cell each $\mathrm{ml}$ & \multicolumn{1}{c}{ Inhibition criteria } & Code \\
\hline$>1.00 \times 10^{5}$ & The activity not appearance & - \\
$0.95-1.00 \times 10^{5}$ & The lowest activity & \pm \\
$<0.95 \times 10^{5}$ & The strongest activity & + \\
\hline
\end{tabular}




\section{RESULT}

Two days later, the samples and medium were appeared still sterile and suitable for research material. Result research showed as follows; the diethyl ether extract of pulverized leaf of Benalu duku were produced anti proliferation activity to myeloma culture cell as illustrate at table 2 at below. At $1.1 \mu \mathrm{g} / \mathrm{ml}$ of the crude extract of diethyl ether of Dendrophthoe species leaves, was not appeared an anti proliferation activities yet on myeloma

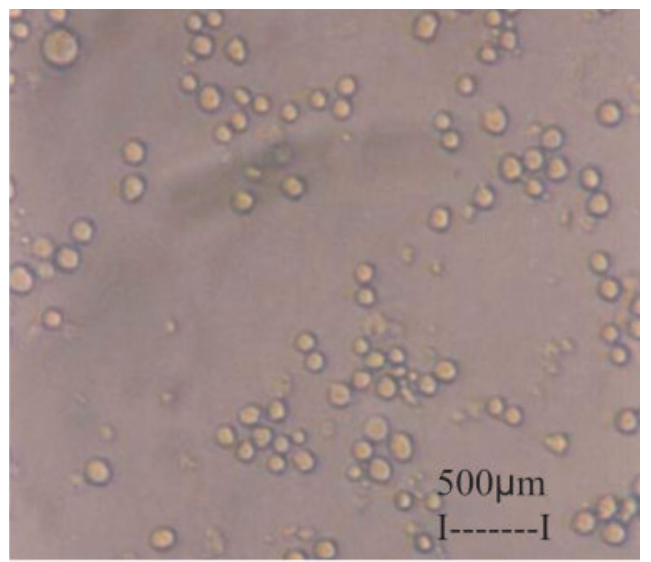

Figure 2. The myeloma culture cell after treats by crude extract diethyl ether of Dendrophthoe species at $11.0 \mu \mathrm{g} / \mathrm{ml}$ (200×).

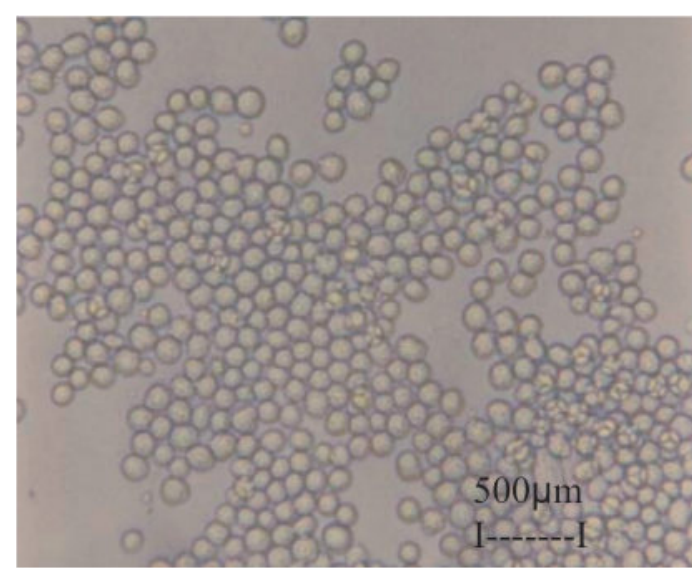

Figure 3. The myeloma culture cell after treated by RPMI medium as control $(200 \times)$.

culture cell. Similar phenomena was seen on concentration of $5.5 \mu \mathrm{g} / \mathrm{ml}$. But start on $11 \mu \mathrm{g} / \mathrm{ml}$, the crude extract of diethyl ether of Dendrophthoe species leaf were seen have an anti proliferation activities against to myeloma culture cell. At figure 2 appeared clearly that since of $11.0 \mu \mathrm{g} / \mathrm{ml}$ extract Dendrophthoe species. leaves have anti proliferation activities to myeloma cells $(\mathrm{p}<0.05)$. Figure 3 showed that the RPMI solution was not produced anti proliferation activities on myeloma cells as control groups.

Table 2. The analysis of crude extract diethyl ether of Dendrophthoe species at ranging $1.1 \mu \mathrm{g} / \mathrm{ml}$ to $44 \mu \mathrm{g} / \mathrm{ml}$, against myeloma culture cell

\begin{tabular}{|c|c|c|c|c|}
\hline Concentr. & Diethyl ether & RPMI solution & Available & $\mathrm{p}^{*}$ \\
\hline \multirow{3}{*}{$1.1(\mu \mathrm{g} / \mathrm{ml})$} & $1.79 \times 10^{5}$ & $1.80 \times 10^{5}$ & - & \multirow{3}{*}{$\mathrm{p}>0.05$} \\
\hline & $1.81 \times 10^{5}$ & $1.81 \times 10^{5}$ & - & \\
\hline & $1.78 \times 10^{5}$ & $1.82 \times 10^{5}$ & - & \\
\hline \multirow{3}{*}{$5.5(\mu \mathrm{g} / \mathrm{ml})$} & $1.77 \times 10^{5}$ & $1.60 \times 10^{5}$ & - & \multirow{3}{*}{$\mathrm{p}>0.05$} \\
\hline & $1.77 \times 10^{5}$ & $1.78 \times 10^{5}$ & - & \\
\hline & $1.76 \times 10^{5}$ & $1.84 \times 10^{5}$ & - & \\
\hline \multirow{3}{*}{$11.0(\mu \mathrm{g} / \mathrm{ml})$} & $5.17 \times 10^{4}$ & $1.87 \times 10^{5}$ & + & \multirow{3}{*}{$\mathrm{p}<0.05$} \\
\hline & $4.80 \times 10^{4}$ & $1.81 \times 10^{5}$ & + & \\
\hline & $4.78 \times 10^{4}$ & $1.80 \times 10^{5}$ & + & \\
\hline \multirow{3}{*}{$22.0(\mu \mathrm{g} / \mathrm{ml})$} & $4.76 \times 10^{4}$ & $1.81 \times 10^{5}$ & + & \multirow{3}{*}{$\mathrm{p}<0.05$} \\
\hline & $3.12 \times 10^{4}$ & $1.82 \times 10^{5}$ & + & \\
\hline & $3.09 \times 10^{4}$ & $1.83 \times 10^{5}$ & + & \\
\hline \multirow{3}{*}{$33.0(\mu \mathrm{g} / \mathrm{ml})$} & $3.10 \times 10^{4}$ & $1.80 \times 10^{5}$ & + & \multirow{3}{*}{$\mathrm{p}<0.05$} \\
\hline & $3.07 \times 10^{4}$ & $1.79 \times 10^{5}$ & + & \\
\hline & $3.11 \times 10^{4}$ & $1.78 \times 10^{5}$ & + & \\
\hline \multirow{3}{*}{$44.0(\mu \mathrm{g} / \mathrm{ml})$} & $3.09 \times 10^{4}$ & $1.86 \times 10^{5}$ & + & \multirow{3}{*}{$\mathrm{p}<0.05$} \\
\hline & $3.08 \times 10^{4}$ & $1.84 \times 10^{5}$ & + & \\
\hline & $3.07 \times 10^{4}$ & $1.81 \times 10^{5}$ & + & \\
\hline
\end{tabular}

* Compared by independent $\mathrm{t}$ test of MINITAB 13.3 
Table 3. The pharmacodynamic activities of herb medicine against to cancer cell at in vitro test

\begin{tabular}{llcl}
\hline \multicolumn{1}{c}{ Herb medicine } & \multicolumn{1}{c}{ Cancer cell } & $\begin{array}{c}\text { The duration of action by } \\
\text { incubation time dependent }\end{array}$ & \multicolumn{1}{c}{ References } \\
\hline $\begin{array}{l}\text { Physallis angulata } \mathrm{L} \\
\text { Eurycoma longifolia } \mathrm{J}\end{array}$ & Myeloma cell & 48 hours & Maryati, Sutrisna $^{20}$ \\
Cola nitida & HeLa cell, WiDr, Raji & 48 hours & ${\text { Dinar } \text { et al. }{ }^{21}}^{\text {Susi }_{\text {et al. }}{ }^{22}}$ \\
\hline
\end{tabular}

The crude extract of 22.0; 33.0 and $44.0 \mu \mathrm{g} / \mathrm{ml}$ were showed significance inhibit ability activities as illustrated table 2 at below. In contras, the crude extracts diethyl ether of Dendrophthoe species at 1.1 and $5.5 \mu \mathrm{g} / \mathrm{ml}$ were not showed inhibit ability activities yet.

\section{DISCUSSION}

The sample beginning at $11.0 \mu \mathrm{g} / \mathrm{ml}$ has a specials unknown substance with inhibition abilities to myeloma culture cell. The unknown substances were dissolved in non-polar solution (diethyl ether). Some Indonesia researcher predicted that substances with inhibition ability activities of Dendrophthoe species were equal to Mistellectin and Viscotoxine substances. That unknown substances better identified as Mistellectin and Viscotoxine like effects referred to mentioned by Ratna et al., and Roostantia et al. ${ }^{11,12}$

We predicted that substances where dissolved in non polar liquid extraction were appeared a complex molecules at waterproof substances of the leaves. The waterproof substances were obtained on chlorophyll region of the Dendrophthoe species at about 10\%. On Chlorophyll region, there are some other actives substances like a phloem, chloroplast and stoma of the leaf at about $65 \%$. Other substances perhaps an un identifying substances with anti proliferation activities as described by Hahn. ${ }^{13,14}$

Arifa et al., ${ }^{15}$ by Fourier Transform Infra-Red Spectrophotometer (FT-IR) have been investigated that unknown substances have a specific profile as follows; the wavelength number as stretching vibration of $\mathrm{C}=$ alkana was appeared at ranging 2926.28 to $2854.9 \mathrm{~cm}^{-1}$. The wavelength number as stretching vibration of $\mathrm{C}=$ aldehide was illustrated at $1736.09 \mathrm{~cm}^{-1}$. The wavelength number of $\mathrm{C}=$ alkena and $\mathrm{N}-\mathrm{H}$ with sharp intensity were identified at ranging 1602.99 to $1658.93 \mathrm{~cm}^{-1}$. The aromatic substances were appeared at $1496.9 \mathrm{~cm}^{-1}$ wavelength number as stretching vibration. The absorbance peak of $\mathrm{C}-\mathrm{H}$ amine, $\mathrm{C}-\mathrm{O}$, acid compounds, carboxylate and Esther were founded at 1060.94 to $1359.94 \mathrm{~cm}^{-1}$ wavelength number as stretching vibration. ${ }^{16}$ Ratna et al., ${ }^{11}$ predicted that unknown substances have been performing as a new compound with amino acid substances for resulted antiproliferation ability activity. But from the result research predicted that unknown substances is lead substances as futuristic compound for anticancer purpose that where consist of amino acid, organic substances and aromatic substances.

The pharmacokinetic and pharmacodynamic of unknown substances that dissolved in diethyl ether of Dendrophthoe species on human and animal experiments was not seen before. But it was predicted that duration of action from unknown substances of Dendrophthoe species dissolved in hot water on rat with infected of myeloma still available at ranging 8 to 12 hours. The elimination half-life (T1/2 $\beta$ ) might be lowest than 1 hours as referrer to Nuraini et $a l .{ }^{3}$ In conclusion, that result showed the available of absorption, distribution, metabolism and excretion (ADME) of Dendrophthoe species as herb medicine on infected subject was shortest than synthetics medicine. ${ }^{17,18}$

The initial of action of unknown substances of Dendrophthoe species after extracted by diethyl ether against to myeloma cell at this test was obtained on a view minutes after dropped. The duration of action at in vitro test of Dendrophthoe species was appeared at 24 to 48 hours after dropped. These result showed that the pharmacodynamic action of unknown substances of Dendrophthoe species after extracted by diethyl ether on in vitro test was longer than in vivo test as explained by Nuraini et al., ${ }^{3}$ (the duration of action at in vivo test at ranging 6 to 12 hours after treatment). But unknown substances of Dendrophthoe species that dissolved on hot water or other polar solvent at in vitro test as described by Roostantia et al., ${ }^{2}$ and Nuraini ${ }^{19}$ were showed similar of other unknown substances of herb medicine as an anti cancer as referred to table 3 .

The phytochemical analysis of crude extract has revealed macromolecules of Dendrophthoe species to be among the chemical constituent contained within it. The macromolecules were shown to produced anti cancer activities. ${ }^{2}$ However, the anti cancer effect of plants containing macromolecules actually depends on type and content of their substances in plants as described by Nuraini. ${ }^{19}$ The active substances of Dendrophthoe species from South of Sumatera (Muara Enim) was shown strongest than Dendrophthoe species from Magelang. The other substances of macromolecules as Tannins perhaps have an anti cancer activity. Tannins are polyphenolic compounds and already available on herb medicine. ${ }^{23}$ Tannins have an antiproliferation as an interfere substance of biosynthesis of eukaryotic cell by uncoupling oxidative phosphorylation. ${ }^{24,25}$ 


\section{ACKNOWLEDGEMENTS}

The author is grateful thank to Rector of Airlangga University, Department of Education, Republic of Indonesia, for giving the sponsorship of this research by loan of institutional income non-tax at programs 2006/2007. I also thank to Director of the Center of Veterinary Pharmaceutics, Directorate of Livestock Services, Agriculture Department, Surabaya (Indonesia) for enabling this work to be undertaken.

\section{REFERENCES}

1. Agus P. The pattern of $\mathrm{p} 53$ gene mutations on oral squamous cell carcinoma. Dent J (Majalah Kedokteran Gigi) 2007; 40(3):119-22.

2. Roostantia I, Lazuardi M, Ratna SM. The comparison of the efficacy to inhibit myeloma cells between Benalu duku and Benalu tea versus Metotrexate. Ebers Papyrus 2000; 6(1):13-21.

3. Nuraini F, Lazuardi M, Farida S. The study of anti cancer effect of Benalu duku (Dendrophthoe spec.,) infusion to the myeloma induced rat. J Ked YARSI 2000; 8(1):59-71.

4. Lazuardi M. Antiproliferation activity of the crude ethanol extracts of Dendrophthoe petandra L. Miq against Myeloma culture cell. The Indon. J Nat Prod. 2007; 6(3):103-6.

5. Lazuardi M. Antiproliferative activity of methanol extract of Benalu duku leaf (Dendrophthoe spec.,) against to In vitro myeloma cell. J Trad Med 2007; 11(39):9-13.

6. Widiyatno TV, Sianita N, Farida N, Susilo S, Lazuardi M. In vitro antiproliferative effect of Benalu duku on myeloma cells. Vet Med J 2007; 23(2):96-101.

7. Nuraini F, Ratna SM, Roostantia I, Lazuardi M. The in vitro study of antiproliferation activities ethyl acetate extract of Benalu duku leaves against to myeloma cells. Final report. Surabaya (Tx): Airlangga University. Office Research and Social Work; 2007. Oct. Report No. 678/J03.2/PG/2007. p. $1-40$

8. Caroline. The antioxidant and free radicals test and determination of EC50 from leaf of green Cincao (Cyclea barbata Miers). J Nat Med 2005; 4(1):11-18.

9. Roostantia I, Ratna SM, Lazuardi M. The explored In vitro test of Tripamidium. Medika Eksakta 2003; 4(3):170-5.

10. World Health Organization. Health Research Methodology: a guide for training in research method. Basel, Switzerland: World Health Organization; 1999. p. 94-103.

11. Ratna SM, Roostantia I, Wahyudi TW, Lazuardi M. The amino acid surveillance of Benalu duku leaf extract. J Trad Med 2007; 11(39):14-8.

12. Roostantia I, Ratna SM, Lazuardi M. The determination of $50 \%$ lethal dose infuse of Benalu duku in mice (Mus musculus Albinos/Balb-c) by oral administration. J Nat Med 2007; 6(1): 38-4.

13. Hahn Petra. Apoptoseinduzierende und antimutagene Wirkung von Viscum album L. auf humane Zellkulturen. Dissertation. Swedish: Fachbereich Biologie, Universität Kaiserslauteren; 2000. p. 61-134.

14. Alvin N. Textbook of modern biology. New York, London, Sidney: John Willey and Sons; 2000. p. 59-95.
15. Arifa M, Roostantia I, Ratna SM. Identification function substance extract of Benalu duku by Fourier Spectrophotometer Infra Red. Final report. Surabaya (Tx); Medical Faculty Airlangga University. Office Medical Research Unit; 2007 March. Report No. 10. p. 3-25.

16. Lazuardi M. Optimizing profile of amino acid analysis of Benalu duku leaf (Dendrophthoe species) using chromatography. Proceeding on National Congress of Multi Discipline Research Development of Herbal in Indonesia, March of $6^{\text {th }}, 2008$. Yogyakarta: Working Groups of Allergy and Immunology Association, Traditional Medicine Research Groups of Medical Faculty Gadjah Mada University and Medical Faculty Gadjah Mada University; p. 112-9.

17. Wahyu D, Sumi W, Nelly CS. The stimulant influence of ethanol extract of Pule cortex (Alstonia scholaris (L).Br.) on many kind of concentrations on mice. J Nat Med 2006; 5(1): 44-9.

18. Suherman J, Susi E, Fauziah O, Asmah R, Wan Nor Izzah WZ. The Influence of Kola fruit extracted against to enzyme activity of rat liver after induced by liver cancer. Proceeding on National Congress of Multi Discipline Research Development of Herbal in Indonesia, March of $6^{\text {th }}, 2008$. Yogyakarta: Working Groups of Allergy and Immunology Association, Traditional Medicine Research Groups of Medical Faculty Gadjah Mada University and Medical Faculty Gadjah Mada University; p. 140-7.

19. Nuraini F. An in vitro analysis of antiproliferation activity of methanol extract of leaves of benalu duku from Magelang and from Muara Enim. Proceeding on National Congress of Multi Discipline Research Development of Herbal in Indonesia, March of $6^{\text {th }}, 2008$. Yogyakarta: Working Groups of Allergy and Immunology Association, Traditional Medicine Research Groups of Medical Faculty Gadjah Mada University and Medical Faculty Gadjah Mada University. p 1-10.

20. Maryati, Sutrisna EM. Cytotoxic potention of Ceplukan trees (Physallis angulata L) to myeloma cell. Proceeding on National Congress of Multi Discipline Research Development of Herbal in Indonesia, March of $6^{\text {th }}, 2008$. Yogyakarta: Working Groups of Allergy and Immunology Association, Traditional Medicine Research Groups of Medical Faculty Gadjah Mada University and Medical Faculty Gadjah Mada University; p. 133-9.

21. Dinar SCW, Subagus W, Mae SH. Characterization and in vitro cytotoxic assay isolate from Akar Pasak Bumi (Euricoma longifolia Jack) from West Kalimantan Jungle. Proceeding on National Congress of Multi Discipline Research Development of Herbal in Indonesia, March of $6^{\text {th }}, 2008$. Yogyakarta: Working Groups of Allergy and Immunology Association, Traditional Medicine Research Groups of Medical Faculty Gadjah Mada University and Medical Faculty Gadjah Mada University; p. 63-70.

22. Susi E, Himmi M, Suherman J, Fauziah O, Asmah R, Wan Noor Izah WZ. The determination of action mechanism of Kola fruits extract (cola nitida) on breast cancer culture cell (MCF-7) by Flow Cytometri. Proceeding on National Congress of Multi Discipline Research Development of Herbal in Indonesia, March of $6^{\text {th }}$, 2008. Yogyakarta: Working Groups of Allergy and Immunology Association, Traditional Medicine Research Groups of Medical Faculty Gadjah Mada University and Medical Faculty Gadjah Mada University; p. 147-54.

23. Bate Smith EC. The phenolic constituents of plants and their taxonomic significance 1, Dicotyledons. J Linn Soc Bot 1962; 58:95-73.

24. Martin RJ. Mode of action of anthelmintic drugs. Vet J 1997; 154:11-34.

25. Sulaiman MM, Mamman M, Aliu YO, Ajanusi JO. Anthelmintic activity of the crude methanol extracts of Xylopia aethiopica against Nippostrongylus brasiliensis in rats. Veterinarski Arhiv 2005; 75(6):487-95. 